Teologia i Moralność, Volumen 13(2018), numer 2(24)

doi: 10.14746/tim.2018.24.2.13

ORCID: /0000-0002-7878-7558

\author{
ADAM CZABAŃSKI \\ Uniwersytet Medyczny w Poznaniu \\ Wydział Nauk o Zdrowiu \\ JANUSZ MARIAŃSKI \\ Katolicki Uniwersytet Lubelski Jana Pawła II \\ Wydział Nauk Społecznych
}

\title{
Problematyka samobójstw w ujęciu Marii Jarosz
}

Samobójstwo człowieka wzbudza pytania o przyczyny i motywy. Można tu przyjąć rozmaite perspektywy badawcze. Z pewnością interesujące są próby zrozumienia tego społecznego fenomenu od strony psychologicznej czy nawet psychiatrycznej. Mimo że śmierć samobójcza dotyka konkretnych jednostek, to ma także wymiar społeczny. Analiza jej społecznego podłoża i uwarunkowań należy do kompetencji socjologii. Od końca XIX wieku za sprawą słynnego dzieła Émile’a Durkheima o samobójstwie (Durkheim 2006), rozpoczęły się socjologiczne naukowe dociekania zmierzające do poznania tego zjawiska. Samobójstwa są nie tylko ważnym problemem społecznym, ale i wskaźnikiem kondycji i integracji (lub dezintegracji) społeczeństwa. Nasilanie się zjawiska samobójstw stanowi ważny symptom anomii społecznej.

Profesor Maria Jarosz przyjęła za Durkheimem, że samobójstwo jest niezwykle czułym wskaźnikiem integracji i w ogóle kondycji społeczeństwa. Podjęła się badania tematu, który od dziesięcioleci był w PRL-u objęty milczeniem. Stopniowo rozszerzała swoje naukowe dociekania, zawsze jednak wiążąc je z zagadnieniem samobójstw. Podejmowała więc takie zagadnienia, jak: nierówności społeczne, sprawiedliwość społeczna (Jarosz 2005c; Jarosz 2008; Jarosz 2010; Jarosz 2013b; Jarosz 2015b) i etyczna. Stała się klasykiem polskiej suicydologii. W ogromnym dorobku naukowym prof. Marii Jarosz, liczącym 50 książek i ponad 300 artykułów naukowych, prace poświęcone problematyce samobójstw są szczególnie cenne. Celem artykułu jest poznanie 
jej inspiracji w zakresie badań suicydologicznych oraz prześledzenie jej socjologicznej koncepcji w ujmowaniu zjawiska samobójstw. W interpretacji socjologicznej wyjaśnia się problem samobójstwa w szerszym kontekście, w warunkach wielkich społecznych, gospodarczych i politycznych transformacji.

\section{Geneza zainteresowań suicydologicznych Marii Jarosz}

Bardzo wiele na temat genezy zainteresowania profesor Marii Jarosz tematyką suicydologiczną można znaleźć we wstępach do jej książek (Jarosz 1997, s. 7-11; Jarosz 2013a, s. 7-10). Pisze ona, że tych motywów fascynacji badawczych fenomenem samozniszczenia było kilka. To, co dla niej charakterystyczne i co świadczy o jej wielkiej ludzkiej wrażliwości, to kolejność podawania tych motywów. Na pierwszym miejscu Maria Jarosz wymieniała podłoże sentymentalne. Tak o tym pisała:

Śmierć, zwłaszcza samobójcza, jest prawie zawsze tragedią dla bliskich, czasami, gdy okoliczności są szczególnie dramatyczne, na przykład kiedy życie odbiera sobie dziecko, śmierć doświadcza również ludzi obcych. Dla mnie silnym wstrząsem było samobójstwo dziewczynki (opiekującej się młodszym rodzeństwem), później zaś nowojorska, samobójcza śmierć Jerzego Kosińskiego, pisarza i mojego przyjaciela. Myślę, że każde z tych zdarzeń z osobna pełniło rolę impulsu wciągającego mnie w orbitę zainteresowania podłożem autodestrukcji (Jarosz 2013a, s. 7).

Kolejnym motywem podjęcia badań nad zjawiskiem samobójstw stały się dla prof. Marii Jarosz jej, jak to sama zaznaczyła: „charakterologiczne inklinacje”. Wyjaśniała to dalej swoimi cechami osobowości: „skłaniającymi do analizy tych akurat problemów, których naukowa popularność jest, z reguły, odwrotnie proporcjonalna do ich społecznego znaczenia" (Jarosz 2013a, s. 8). Gdy po przymusowym bezrobociu znalazła się w Głównym Urzędzie Statystycznym, mimo zakazu ówczesnej władzy komunistycznej podjęła pionierskie badania nad fenomenem samobójstw. Badania te spotkały się z wielkim międzynarodowym uznaniem, co stało się motorem jej dalszych naukowych działań. Z rozbrajającą szczerością napisała: „Przyznaję się przeto: do analiz fenomenu samozniszczenia popycha mnie także próżność. Są one bowiem źródłem moich osobistych satysfakcji” (Jarosz 2013a, s. 9).

Sama Maria Jarosz wielokrotnie przyznawała się do naukowych inspiracji wynikających z lektury Le suicide Émile'a Durkheima (Jarosz 1997, s. 9; Jarosz 2013a, s. 9; Jarosz 2015a, s. 9). Zwracała przy tym uwagę, że koncepcja Durkheima stwarza możliwość analizy społeczeństwa wychodzącej poza ele- 
menty jego struktury i pozwala podjęcie ujęcia syntetyzującego, porządkującego pole badań. Należy ponadto zauważyć, że zainteresowanie zjawiskiem samobójstw przejawia się także w socjologicznej tożsamości Marii Jarosz, sprawiającej, że badania te dotyczą dużych zbiorowości i uprawniają do formułowania wniosków uogólniających.

W socjologicznej perspektywie badań nad postawami i zachowaniami autodestrukcyjnymi przyjmuje się jako punkt wyjścia jednostkę, a nie społeczeństwo. Analizuje się akt samobójczy w kontekście jego społecznych uwarunkowań. Jeżeli człowiek jest częścią określonego społeczeństwa, to źródeł samobójstw należy szukać w zakłóceniach tego społeczeństwa i badać je jako efekt dezintegracji społeczeństwa, a nie jako przejaw dezintegracji osobowości samobójcy. Często nie potrafimy odpowiedzieć na pytanie, dlaczego ludzie decydują się na odebranie sobie życia, ale możemy poszukiwać wspólnych uwarunkowań samobójstw i wskazywać na ich społeczny kontekst. U podłoża podobieństw i odmienności samobójstw leżą zmienne demograficzne, społeczne, statusowe i sytuacyjne, czyli cały kompleks interferujących czynników. Indywidualne motywy działań samobójczych ujmuje się w kontekście warunków społecznych, zapobiegających lub sprzyjających zamachom na własne życie (Jarosz, Kozak 2016, s. 206).

\section{Koncepcja samobójstw Marii Jarosz}

W koncepcji samobójstw Marii Jarosz na plan pierwszy wysuwa się jej socjologiczny charakter. Wielokrotnie krytykowała ona podejście psychiatryczne, które szuka wyjaśnienia zjawiska samobójstw w zaburzeniach psychicznych lub szczególnie predestynujących do samobójstwa cechach ofiary. Tymczasem pojęcie „woli życia” nadużywane przez Janusza Czapińskiego i „samobójstwo jako efekt utraty woli życia” nie tłumaczy na przykład podwyższonej skłonności do samobójstw wśród wojskowych, więźniów oraz osób bezrobotnych (Jarosz 2013a, s. 30-31). Jako socjolog zwraca Maria Jarosz uwagę na powiązanie samobójstw z warunkami społecznego, politycznego i ekonomicznego życia jednostek. Zgodnie z jej wykładnią socjologiczny kierunek badań nad zachowaniami samobójczymi kładzie nacisk na uwarunkowania społeczne, czyli ponadjednostkowe.

Pisze w swojej książce:

[...] skoro człowiek jest częścią określonego społeczeństwa, to źródeł samobójstw należy szukać w zakłóceniach funkcjonowania tego społeczeństwa. Samobójstwo jako zjawisko społeczne należy więc badać jako efekt dezintegracji społeczeństwa, a nie jako przejaw dezintegracji osobowości samobójcy. Nie oznacza to 
lekceważenia indywidualnych motywów działań samobójczych, ale przesunięcie zainteresowań z działań jednostkowych na działania stanowiące ich wspólny mianownik: warunki społeczne zapobiegające lub sprzyjające zamachom na własne życie. Wyraźne są ich wymierne wyznaczniki dowodzące zróżnicowanego nasilenia i zmienności lub stałości trendów społecznych (Jarosz 2013 a, s. 32).

Ponadto szczególnie wyraźne są inspiracje teorią samobójstw Émile'a Durkheima. Na szczególną uwagę zasługuje fakt, że jest to koncepcja dynamiczna, a jednocześnie spójna. Wszak od samego początku za Durkheimem wskazywała na samobójstwo jako na znakomity wskaźnik stopnia integracji społeczeństwa (Jarosz 1975; Jarosz 1977, s. 325-350; Jarosz 1978, s. 65-101; Jarosz 1980; Jarosz 1985, s. 449-464). Podtrzymywała ten pogląd także w swoich ostatnich publikacjach (Jarosz 2004; Jarosz 2005a; Jarosz 2005 b, s. 1-13; Jarosz 2012; Jarosz 2013a; Jarosz 2015a, s. 5-17). Oznacza to, że im wyższe są współczynniki śmierci samobójczej, tym silniejsza jest dezintegracja społeczeństwa, a im niższe - tym wyższa integracja i lepsza kondycja społeczeństwa.

Tym, co sytuuje badania prof. Marii Jarosz w kategorii badań klasycznych, jest ich szeroki zakres temporalny rozpinający się od roku 1951 i obejmujący także pierwsze lata drugiej dekady XXI wieku. Ów naukowy rozmach można w pewnych aspektach porównać tylko do badań Brunona Hołysta (Hołyst 1968, s. 22-23; Hołyst 1983; Hołyst 2012; Hołyst 2013, s. 11-290). Pamiętać jednakże należy o wewnętrznej dyscyplinie naukowej prof. Marii Jarosz, konsekwentnie wysoko ceniącej zwłaszcza socjologiczne ujmowanie problematyki samobójstw, $\mathrm{z}$ akcentowaniem różnych czynników zmniejszających lub zwiększających prawdopodobieństwo zachowań samobójczych.

Warto pokrótce przedstawić wnioski z badań Marii Jarosz, które przez wiele lat nadawały pewien kierunek naukowych dyskusji skupiających się na fenomenie samobójstw. Od początku prowadzenia statystyk samobójstw w Polsce (czyli od 1951 roku), zgodnych z międzynarodową statystyką zgonów, liczba samobójstw wzrosła o 400\%. W tym czasie liczba ludności wzrosła z 25,5 miliona do około 38 milionów w 2011 roku (Jarosz 2013a, s. 78; Jarosz 2015a, s. 7). Zdaniem Marii Jarosz, tempo wzrostu liczby samobójstw w Polsce jest nierównomierne. Obserwowała ona wahania w dynamice liczby samobójstw w Polsce i pisała o tym w licznych pracach (Jarosz 1995, s. 9-31; Jarosz, Krawczyk 1995b; Jarosz 1997 s. 83-85; Jarosz 1999, s. 115-126; Jarosz 2004, Jarosz 2013a, s. 78-80; Jarosz 2015a, s. 9). Współczynniki samobójstw rosły najszybciej w latach pięćdziesiątych i sześćdziesiątych XX wieku.

$\mathrm{Z}$ kolei w latach siedemdziesiątych (era gierkowska) nastąpiło pewne wyhamowanie tych tendencji i niewielkie coroczne wahania liczby samobójstw w kolejnych latach. Tym, co szczególnie podkreślała prof. Maria Jarosz - 
był rok 1981, kiedy to nastąpił znaczny spadek liczby samobójstw w Polsce (o 35\%). Uczona wiązała ten spadek jednoznacznie z nadziejami związanymi z „Solidarnością” i - można powiedzieć - sytuacją rewolucyjną. Rozbudzenie społecznych nadziei na zmiany w Polsce skutecznie powstrzymywało ludzi od lekkomyślnego pozbawiania się życia, które po zwycięstwie nad „onymi” może się przydać, nabrać sensu. Kolejny raz potwierdziła się teoria samobójstw Émile'a Durkheima, że samobójstwa są czułym wskaźnikiem integracji i kondycji społeczeństwa. W następującym bezpośrednio po tym okresie stanie wojennym doszło do znacznego wzrostu współczynników śmierci samobójczej.

Kolejny przełom w Polsce to rok 1990, czyli początek bezkrwawych przemian, który również zaowocował spadkiem liczby samobójstw. Lata dziewięćdziesiąte XX wieku zaznaczyły się w Polsce wzrostem zjawiska bezrobocia, biedy i braku nadziei na poprawę sytuacji. Nastąpiło więc rozczarowanie efektami transformacji, co przełożyło się na rosnące współczynniki śmierci samobójczej. O ile jednak w latach dziewięćdziesiątych XX wieku każdego roku popełniało samobójstwo ponad 5 tysięcy osób, czyli mniej więcej tyle, ile ginie w wypadkach drogowych, o tyle w czasach światowego kryzysu finansowego i gospodarczego, skutkującego wzrostem bezrobocia i nierówności społecznych, każdego roku popełnia samobójstwo ponad 6 tysięcy osób. Po okresie względnej stabilizacji współczynniki samobójstw zaczęły ponownie rosnąć. Zwłaszcza bezrobocie stawało się jednym z najważniejszych czynników inspirujących śmierć samobójczą. Bezrobotni i rolnicy to grupy najczęściej wykluczające się przez samobójstwo z życia.

Analizując zjawisko samobójstw w Polsce w kolejnych dziesięcioleciach, Maria Jarosz zauważyła rosnący udział mieszkańców wsi i malejący mieszkańców miast. Już w drugiej połowie lat siedemdziesiątych XX wieku stwierdzić można było tendencje wyrównywania się udziału mieszkańców miast i wsi w strukturze zgonów samobójczych. Przełomowym rokiem był rok 1978, kiedy to wskaźniki śmierci samobójczej w obu środowiskach były analogiczne (Jarosz 1980, s. 149). Jak napisała wówczas: „Upraszczając: w roku 1951 na $40 \%$ ludności miejskiej przypadało 50\% popełnionych samobójstw, natomiast w roku 1978 na 60\% ludności miejskiej przypadało nadal 50\% popełnionych samobójstw" (Jarosz 2013a, s. 81). Dyskutując w kwestii obalenia czy też potwierdzenia klasycznej Durkheimowskiej teorii samobójstw, Maria Jarosz zauważyła, że w tej teorii wskazuje się na samobójstwo jako na zjawisko typowo miejskie. Nasilenie samobójstw w miastach wynikać miało z dezintegracji środowiska miejskiego, rozluźnienia więzi sąsiedzkich i rodzinnych. Procesy rozwoju ekonomicznego i społecznego doprowadziły do znacznego ujednolicenia obu środowisk, co oznaczało osłabienie tradycyjnych kulturowych mechanizmów integracyjnych, charakterystycznych dla dawnych środowisk wiejskich. 
Zwrócić jednak należy uwagę na to, że współcześnie w środowiskach wiejskich powtórzył się określony zespół czynników, które niegdyś w mieście doprowadziły do nasilenia się zachowań samobójczych (np. osłabienie więzi rodzinnych, sąsiedzkich i środowiskowych oraz związane z tym poczucie izolacji i osamotnienia, narastające procesy dezintegracyjne). Jak słusznie zauważa Maria Jarosz: „Jest to więc wciąż to samo - sformułowane przez klasyków socjologii - podłoże zjawisk dewiacyjnych" (Jarosz 2013a, s. 85). W dalszych konstatacjach uczonej pojawia się uwaga dotycząca malenia liczby gospodarstw rolnych i jednoczesnego wzrostu liczby ludności pozarolniczej, w tym ludności bez zajęcia. Według niej wzrost samobójstw wśród ludności wiejskiej generowali przede wszystkim pracownicy dawnych państwowych gospodarstw rolnych. Wśród rolników i hodowców też wzrosły wskaźniki samobójstw z powodu trudności w przystosowywaniu się do twardych reguł gospodarki rynkowej. Tak więc kluczowe okazują się względy gospodarcze i zjawisko bezrobocia, wzmagające nierówności społeczne właśnie w środowiskach wiejskich (Jarosz 2015a, s. 11).

Jeśli chodzi o regionalne zróżnicowanie samobójstw w Polsce, to Maria Jarosz zauważyła, że: „najwyższe wskaźniki samobójstw występują na tych obszarach, w których jest największe nasilenie problemów socjalno-bytowych, szczególnie związanych z sytuacją na rynku pracy oraz brakiem regionalnych perspektyw rozwojowych. Tego typu województwa tworzą szczególny syndrom suicydogenny stymulowany przez określone czynniki sytuacyjne" (Jarosz 2013a, s. 92-93). W światowej statystyce śmierci samobójczej Polska zajmuje miejsce środkowe i najniższe w grupie krajów postkomunistycznych (najwyższe współczynniki samobójstw ma Rosja i kraje nadbałtyckie).

Jeżeli nawet wybitna polska badaczka procesów związanych z samobójstwem nie abstrahuje całkowicie od szczególnych i jednostkowych motywów podjęcia przez człowieka decyzji samobójczych (np. poczucia osamotnienia, izolacji społecznej, sytuacji stresowych związanych z rodziną czy pracą), to $\mathrm{w}$ interpretacjach stricte socjologicznych poszukuje przede wszystkim wspólnych cech, generalnych uwarunkowań większości przypadków.

Jest bowiem tak, że człowiek popełnia samobójstwo z najrozmaitszych powodów, mniej lub bardziej uświadomionych, mniej lub bardziej ze sobą powiązanych. Bezpośrednie przyczyny sprawcze bywają trudne do ustalenia nawet $\mathrm{w}$ indywidualnym przypadku i z pewnością nie dają się ekstrapolować na analizę szerszej zbiorowości. Skoro więc człowiek, każdy z osobna, kieruje się własnymi, indywidualnymi motywami popełniania samobójstwa, to nie jest łatwo znaleźć wspólny mianownik dla poszczególnych przypadków. Samobójstwa są jednak zjawiskiem społecznym, autodestrukcyjna aktywność podejmowana jest tak często, że samobójcy stanowią znaczną kategorię w strukturze całej populacji (Jarosz, Kozak s. 205-206). 
Jeżeli nawet tak jest, że samobójstwa są popełniane $\mathrm{z}$ różnych powodów i każdy samobójca kieruje się własnymi indywidualnymi motywami odebrania sobie życia, to w rzeczywistości istnieje pewien szczególny syndrom sytuacyjny skłaniający określone jednostki do zachowań autodestrukcyjnych (Jarosz 2002 s. 9). Rosnące wskaźniki śmierci samobójczej konstatują socjologowie w okresach nasilania się procesów dezakceptacji społecznej, kryzysu wartości i obniżania się rangi współdziałania społecznego, malejące zaś w sytuacjach integracji społecznej. Zbiorowość samobójców można scharakteryzować przede wszystkim za pomocą cech demograficznych, tj. płci i wieku.

\section{Wiodące tematy badawcze}

Ważny temat podjęty przez Marię Jarosz obejmował zachowania samobójcze dzieci i młodzieży. Uczona bardzo wyraźnie rozdzielała zjawisko samobójstw od prób samobójczych. Pisała o tym w następujący sposób: „Nieuprawnione jest bowiem [...] łączenie zachowań o różnej wykrywalności i odmiennej strukturze społeczno-demograficznej osób je przejawiających. Jeśli ponadto weźmiemy pod uwagę odmienną intencję autoagresji [...] to całościowe ujęcie problemu mogłoby zdeformować jego rzeczywisty, empiryczny obraz" (Jarosz 1997, s. 102). Zauważała ona, że z roku na rok rosną współczynniki samobójstw i prób samobójczych wśród młodzieży. Już w połowie lat siedemdziesiątych XX wieku podjęła badania tysięcy dzieci i młodzieży z rodzin dysfunkcjonalnych. Do dziś są to wciąż jedyne reprezentatywne badania zjawiska samobójstw wśród uczniów oraz dzieci z rodzin zdezorganizowanych (Jarosz 1979, s. 180-193). Z badań tych wynikały interesujące wnioski. Maria Jarosz stwierdziła, że istnieje wyraźna zależność między pozycją społeczną rodziców a nasileniem samobójstw ich potomstwa. Najwyższe wskaźniki prób samobójczych odnotowywano wśród dzieci robotników niewykwalifikowanych. Ponadto Uczona ustaliła, że dziewczęta trzykrotnie częściej niż chłopcy podejmują próby samobójcze, natomiast chłopcy pięciokrotnie częściej niż dziewczęta popełniają samobójstwa. Stwierdziła też, że zachowania samobójcze podejmują z reguły uczniowie słabsi (Jarosz 1997, s. 112).

Na uwagę zasługuje fragment pracy Marii Jarosz odnoszący się do szczególnego nasilenia samobójstw i prób samobójczych wśród młodzieży z rodzin dysfunkcjonalnych:

[...] nie ulega wątpliwości, że wszelkie formy zachowań autodestrukcyjnych (łącznie z samouszkodzeniem) wyrosły na podłożu niekorzystnej sytuacji rodzinnej i są wskaźnikiem społecznego nieprzystosowania sprawcy aktu autoagresji. Szczególnie silnie usposabiający do samoniszczenia jest syndrom sytuacyjny: ku- 
mulowanie się kłopotów domowych i szkolnych wtedy, kiedy ani dom, ani szkoła nie wiąże pozytywnie dziecka. Samobójstwo jest przy tym jedną z możliwych dróg zmiany istniejącej sytuacji - obok ucieczek, alkoholizmu, zachowań przestępczych (Jarosz 2013a, s. 106).

Zauważyła ona utrzymujący się także w innych krajach trend „odmładzania się" struktury wieku samobójców, czyli wzrost udziału w strukturze samobójstw roczników najmłodszych, mimo że zróżnicowanie nasilenia samobójstw według wieku jest cechą względnie trwałą (Jarosz 1997, s. 115-116; Jarosz 2013a, s. 108).

Profesor Maria Jarosz wniosła do polskiej suicydologii interesujące rozważania dotyczące wyjaśnienia dysproporcji między śmiercią samobójczą mężczyzn i kobiet. Polska sytuuje się wśród krajów, gdzie te dysproporcje są szczególnie wyraziste. Na jedno samobójstwo kobiety przypada sześć samobójstw mężczyzn. Sama Uczona zauważyła, że jednoznaczna odpowiedź na tę kwestię jest trudna. Chodzi tu bowiem o współwystępowanie całego kompleksu uwarunkowań. Zwracała więc uwagę na kilka możliwych wyjaśnień tego społecznego fenomenu. Zauważała, że niegdyś istniały duże dzietności polskich kobiet. Macierzyństwo miało być więc tą barierą chroniącą je od podejmowania zachowań autoagresywnych (Jarosz 1997, s. 122-123). W latach osiemdziesiątych XX wieku w innych krajach europejskich o wysokich dzietnościach kobiet (Portugalii, Grecji, Hiszpanii) kobiety relatywnie rzadko popełniały samobójstwo. Od tamtych czasów radykalnie zmniejszył się przyrost naturalny i w związku z tym dzietności kobiet. W Polsce trend ten zaczął się na początku lat dziewięćdziesiątych XX wieku. Maria Jarosz wyraziła wówczas przekonanie, że wzgląd na dzieci już urodzone, które trzeba wychowywać, wydaje się jednym z najważniejszych czynników skutecznie powstrzymujących kobiety-matki od samobójstw. Jednak w początkach XXI wieku dzietności kobiet jeszcze bardziej spadły i należy zastanowić się nad innymi możliwymi wythumaczeniami stosunkowo niewielkiej liczby samobójstw kobiet w Polsce.

Maria Jarosz zwracała więc swoją uwagę na uwarunkowania kulturowe omawianego zjawiska. Uczona zdecydowała się na hipotezę: „o relatywnie wysokiej $\mathrm{z}$ dawien dawna (w porównaniu $\mathrm{z}$ innymi krajami) pozycji polskiej kobiety. Wiązało to się z jej szczególną rolą pielęgnowania (i przekazywania dzieciom) wartości patriotycznych i religijnych [...]" (Jarosz 2013a, s. 114-115). Ponadto, jej zdaniem, należy zwrócić uwagę na status wykształceniowy polskich kobiet, który jest wysoki w porównaniu ze współczynnikiem wykształcenia mężczyzn. Pisze ona o tym następująco: „Wśród kobiet z wyższym wykształceniem odsetki kobiet zawodowo czynnych oscylują wokół $80 \%$. Co więcej, odnotowano w Polsce szybsze tempo wzrostu pozio- 
mu wykształcenia wśród kobiet niż wśród mężczyzn" (Jarosz 2013a, s. 113). W ostatnich swoich publikacjach naukowych prof. Maria Jarosz zwracała uwagę na aktywność zawodową kobiet i dostrzegała takie prace, które wiązały się z wyższym dla kobiet niż dla mężczyzn ryzykiem śmierci samobójczej. „Po pierwsze, zagrożone są robotnice zatrudnione na budowach i w transporcie, a także w przemyśle i górnictwie [...]” (Jarosz 2015a, s. 14).

Zagrożenie samobójstwem było porównywalne u kobiet i mężczyzn, jeśli dotyczyło stanowisk kierowniczych. Zauważyła również, że w ostatnich zwłaszcza latach praca zawodowa staje się dla kobiet coraz ważniejsza i współwystępuje z obowiązkami rodzinnymi.

Dziś kobiety - lepiej wykształcone i często bardziej wydajne od swoich kolegów - nie dadzą się wypchnąć z rynku. Nie pozwolą na ograniczanie ich zawodowej tożsamości [...]. Opinię, że praca zawodowa bardziej nobilituje społecznie niż poświęcenie się wyłącznie dla domu i rodziny, podziela ponad 79\% Polek, przy czym pokaźna ich liczba uważa, że kierowanie ludźmi to bardzo kobiece zajęcie - co jest też przyczynkiem do zmiany stereotypu płci we współczesnym polskim społeczeństwie (Jarosz 2015a, s. 15).

Odnosząc się do światowego kryzysu, Uczona stwierdziła, że w jego wyniku w Polsce pracę utraciło więcej mężczyzn niż kobiet. Ponadto rysują się trendy wyrównywania się zarobków mężczyzn i kobiet. Okazuje się także, że kobiety sukcesywnie stają się bardziej profesjonalne i coraz lepiej osadzone w tworzącej się nowej rzeczywistości.

Zmiana męskich i kobiecych stereotypów zachowań wiąże się, po pierwsze, z przewartościowaniem współczesnego modelu rodziny i pracą kobiet. W rezultacie to, co powstrzymuje kobiety przed samobójstwem, bywa często dla mężczyzn czynnikiem stresującym i suicydogennym. Mężczyzna, w którego świadomości mieści się wciąż wzór macho, często nie potrafi odnaleźć się w sytuacji, w której rządzi często lepiej zarabiająca kobieta [...] W tej sytuacji utrata pracy staje się dla mężczyzny czynnikiem wręcz suicydogennym. Po drugie, owe przewartościowania ról społecznych wyrażają się też w zmianie stereotypów seksualnych [...]. Wszystko to sprawia, że obraz Polski rysuje się jako kraj o silnych Polkach i coraz słabszych Polakach (Jarosz 2015a, s. 15-16).

We wszystkich krajach Europy i świata, w tym także w Polsce, mężczyźni częściej niż kobiety popełniają samobójstwa, choć różne są proporcje tego zjawiska. W Polsce współczynniki śmierci samobójczej kobiet i mężczyzn są najwyższe w przedziale wieku 45-60 lat. Przyczyny tego zjawiska nie są w pełni zbadane. 
W literaturze spotykamy się z różnego typu interpretacjami, powszechnie zwraca się uwagę na większą skuteczność samobójstw mężczyzn wynikającą z wyboru pewniejszych sposobów dokonania samobójstw oraz silniejszej intencji śmierci. Polska (obok Hiszpanii, Portugalii, Włoch) jest jednym z krajów o najniższym udziale kobiet $\mathrm{w}$ strukturze zgonów samobójczych. W społeczeństwie polskim w przybliżeniu jedna kobieta na pięciu mężczyzn umiera na skutek popełnionego samobójstwa, podczas gdy w Japonii na jedną samobójczynię przypada 1,5 samobójcy (Jarosz 2002, s. 10).

Z badań profesor Marii Jarosz wynika także, że istnieją istotne związki nasilenia samobójstw ze stanem cywilnym samobójców. Okazuje się więc, że szczególnie suicydogenne jest bycie wdową, wdowcem lub osobą rozwiedzioną. Samobójstwa tych osób w porównaniu z osobami żonatymi, zamężnymi lub kawalerami i pannami są czterokrotnie częstsze (Jarosz 2013a, s. 118). Według Marii Jarosz czynnikiem szczególnie wzmacniającym zagrożenie samobójstwem jest nagła zmiana stanu cywilnego, zwłaszcza nagłe osamotnienie wywołujące poczucie izolacji, a także społecznego nieprzystosowania. Uczona zwraca uwagę na pierwszy rok bycia wdową lub wdowcem. Ryzyko popełnienia samobójstwa jest wówczas dwukrotnie większe niż w kolejnych latach. Nagłe osamotnienie jest czynnikiem wybitnie suicydogennym, zwłaszcza w sytuacji kumulowania się trudnych problemów życiowych związanych nie tylko z rodziną, ale i z pracą zawodową, zwłaszcza z utratą pracy.

Profesor Maria Jarosz zasłynęła także wnikliwymi studiami nad samobójstwami w strukturze społeczno-zawodowej w polskim społeczeństwie. Zdaniem tej Uczonej, szczególnie determinujące zachowania samobójcze czynniki są związane ze zmianą pracy lub jej utratą, przejściem na emeryturę bądź odgrywaniem nieadekwatnej roli społecznej lub niemożnością zaspokojenia aspiracji społecznych i zawodowych. Szczegółowe analizy objęły już lata siedemdziesiąte XX wieku (Jarosz 1977, s. 325-350), ale także kolejne dekady XX wieku (Jarosz 1995, s. 20-32; Jarosz 1997, s. 151-161) i pierwsze lata XXI stulecia (Jarosz 2013a, s. 144-150). W zależności od współczynnika określającego nasilenie się zjawiska śmierci spowodowanej samobójstwem można wyróżnić pewne kategorie społeczno-zawodowe.

Wśród wniosków z wieloletnich badań na szczególne zainteresowanie zasługują te, które koncentrują się na okresie transformacji z lat dziewięćdziesiątych XX wieku i pierwszych lat XXI wieku. Z ustaleń Marii Jarosz wynika, że najmniej suicydogenną grupą są pracownicy umysłowi. $Z$ kolei do grup osób najczęściej odbierających sobie życie należą pracownicy fizyczni, bezrobotni i rolnicy. Wśród nich najczęściej (ponad 25\%) popełniają samobójstwa pracownicy fizyczni. Badaczka zwróciła także uwagę na to, że to właśnie oni ponieśli największe koszty związane z przebudową polskiej gospodarki. Wystar- 
czy wymienić tu górników, hutników i stoczniowców, spośród których wielu straciło pracę i nie podołało procesom adaptacyjnym do zmienionych warunków społeczno-ekonomicznych. Otwarcie gospodarki rynkowej nie gwarantuje realizacji zasad sprawiedliwości społecznej, a co więcej, właśnie nierówności społeczne są cechą tego nowego systemu (Jarosz 2013a, s. 146-147). Słusznie Maria Jarosz zauważyła, że na samobójstwa w strukturze społeczno-zawodowej ma wpływ nie tylko sytuacja materialna, ale utrata społecznego prestiżu, zwłaszcza w odniesieniu do klasy lub warstwy uznawanej za przodującą (robotnicy). Daje to szczególnie niszczące skutki zwłaszcza w pierwszym okresie transformacji (Jarosz 2013a, s. 148).

Oprócz robotników kolejną grupą, w której już od 1982 roku obserwuje się narastanie zgonów samobójczych, są rolnicy. Przyczyną takiego stanu rzeczy jest postępująca pauperyzacja środowiska wiejskiego, a także problemy z przystosowaniem się do zasad gospodarki rynkowej (Jarosz 2013, s. 148). Zdaniem Marii Jarosz, samobójstwa łączą się nie tylko z problematyką tak zwanych „ludzi zbędnych”, ale także z tymi, którzy korzystając z możliwości społecznego awansu zdobywają wyższe pozycje społeczne.

[...] nawet zdobycie wyższej pozycji społecznej, kariera życiowa mogą się stać przyczyną stanów depresyjnych i nerwicowych. Trudności w pełnieniu nowej roli, problemy adaptacji do gospodarki rynkowej, obawa przed niewywiązywaniem się z nowych obowiązków i utratą pozycji już osiągniętej, lęk przed przyszłością bywają źródłem stanów nerwicowych i depresyjnych, wyrażających się częstokroć samoniszczeniem: alkoholizmem i samobójstwami (Jarosz 2013a, s. 149).

Na szczególną uwagę zasługują - zdaniem Marii Jarosz - bezrobotni, zaliczający się do grup o najwyższym ryzyku śmierci samobójczej. Problem ten dotyczy zresztą szerszej grupy ludzi, bo także tych, którzy odczuwają lęk przed utratą pracy. Sama perspektywa utraty pracy prowadzi tych ludzi do podejmowania decyzji o popełnieniu samobójstwa. Badaczka zwróciła dodatkowo uwagę na negatywny syndrom sytuacyjny, który tu się wytwarza. Postępująca pauperyzacja łączy się z osamotnieniem. Do tego dochodzą niskie kwalifikacje zawodowe i niewiara w poprawę sytuacji w przyszłości (Jarosz 2013a, s. 149). Ważna jest perspektywa znalezienia nowej pracy, a to zależy od wielkości miejscowości. Uczona zadawała sobie pytanie, czy odnotowany po 2008 roku wzrost wskaźników śmierci samobójczej jest zjawiskiem trwałym. Z perspektywy kilku lat widać, że na spadki liczby samobójstw trzeba jeszcze poczekać. Nadzieją napawają jednak spadające odsetki osób bezrobotnych w Polsce, począwszy od 2015 roku, co może przełożyć się także na zredukowanie liczby samobójstw. 


\section{Szczegółowe tematy badawcze}

Samobójstwo jest daleko idącą formą dobrowolnego wykluczenia się z życia społecznego. Ma ono złożone, niekiedy ukryte przyczyny. Można je jednak analizować i wyciągać w miarę wiarygodne wnioski. Nasilenie się liczby podejmowanych decyzji samobójczych, a zwłaszcza dokonanych samobójstw, jest wskaźnikiem, że jako społeczeństwo przeżywamy trudny okres. Badania socjologiczne realizowane przez Marię Jarosz dotyczyły nie tylko całego społeczeństwa polskiego, ale i wybranych grup społecznych. W swoich wieloaspektowych studiach nad zjawiskiem samobójstwa podejmowała ona także badania nad autodestrukcjami w środowiskach zamkniętych (Jarosz 1997, s. 162-180; Jarosz 2013a, s. 151-168).

Na uwagę zasługują więc wnioski z badań nad samobójstwami w więzieniach. Więźniowie pod względem położenia społecznego mogą być traktowani jako wyodrębniona i relatywnie jednolita kategoria społeczna. Z badań wynika, że od 1993 roku notuje się wyraźny spadek zachowań autodestrukcyjnych wśród aresztantów. Samobójstwa są podejmowane 3-6 razy częściej niż w pozostałej populacji. Ponadto 2,5 razy częściej samobójstwa popełniają osoby tymczasowo aresztowane niż skazani na karę pozbawienia wolności. Z badań socjologicznych wynika ponadto, że samobójstwa popełniają zwłaszcza sprawcy najcięższych przestępstw. Szczególnie zwraca uwagę fakt, że samobójcy z więzień pod względem cech demograficznych nie różnią się od populacji samobójców całego kraju. „Jedyną cechą odróżniającą samobójców ze środowisk więziennych od samobójców całego kraju jest miejsce zamieszkania. Tych ostatnich charakteryzuje raczej przynależność do środowisk wiejskich [...], podczas gdy samobójcy w więzieniach pochodzili najczęściej z miasta" (Jarosz 2013a, s. 160-165). Struktura demograficzna (płeć, wiek, stan cywilny) i wykształcenie nie różni samobójców od całej zbiorowości skazanych, jak też nie różni ich od populacji samobójców.

Preferowaną metodą pozbawienia się życia w więzieniu, podobnie jak w wojsku i we wszystkich innych środowiskach w kraju, jest powieszenie się (65\% przypadków). Miejscem śmierci jest najczęściej wspólna cela, czas to z reguły noc albo godziny nieobecności współwięźniów (np. spacer, badania lekarskie). Więźniowie, którzy dokonali aktów autoagresji, byli jednocześnie sprawcami najbardziej agresywnych i niebezpiecznych rodzajów przestępstw (np. przeciwko życiu, wolności, mieniu i własności). Na tle struktury rodzajowej ogółu więźniów samobójcy wyróżniali się nasileniem przestępstw zagrożonych wysokimi karami (Jarosz 2013 b, s. 165 i 167).

Samobójcy w więzieniach nie wykazują - wbrew oczekiwaniom psychiatrów i specjalistów systemów penitencjarnych - odchyleń od norm zdrowia psychicznego, są zatem relatywnie normalni, chociaż niektórzy z nich to ludzie 
marginesu społecznego. „Odbierają sobie życie ludzkie mniej odporni, uwikłani w sytuacje, które rzeczywiście (bądź we własnym mniemaniu) ich przerastają. Nie są w stanie rozwiązać węzła gordyjskiego, w który zapętliła się ich teraźniejszość. Przecinają go, kładąc kres życiu" (Jarosz 2013b, s. 167-168).

W więzieniu samobójstwo (także zakończone śmiercią) jest często postrzegane jako zachowanie honorowe i traktowane - często koniunkturalnie - jako czyn altruistyczny, dokonany w interesie społeczności więziennej. Nie ulega wątpliwości, że tego rodzaju nastawienia charakteryzujące się takim stopniem przyzwolenia zwiększają prawdopodobieństwo samobójstw w więzieniach.

Nigdzie jednak nie ma tak jednoznacznie traumatyzującego i suicydogennego syndromu sytuacyjnego jak w więzieniach właśnie. Składa się nań: nagłe zerwanie kontaktów z całym otoczeniem, ograniczenie kontaktów z najbliższymi (prowadzące częstokroć do ich definitywnego zerwania) i konieczność natychmiastowego podporządkowania się regułom instytucji więziennej. Wszystko to rodzi poczucie wyobcowania, krzywdy, bezradności - a niekiedy także bezsensu dalszego życia (Jarosz 2013 b, s. 167).

Wojsko, podobnie jak i więzienie (każde trochę inaczej), stanowi poddane rygorom, zamknięte środowisko, stymulujące określone typy zachowań, także autodestrukcyjnych. Dla niemałej grupy poborowych służba w wojsku i związany z nią rygoryzm są źródłem nieustającego poczucia zagrożenia i lęku. Także zachowania przypisywane tzw. „fali” w wojsku zwiększały ryzyko autodestrukcji, jednakże od pierwszej dekady XXI wieku zjawisko „fali” i związanych z nią samobójstw praktycznie nie występuje. Wynika to z procesu uzawodowienia armii.

Odwołując się do sytuacji w wojsku, Maria Jarosz dostrzegała spadek liczby samobójstw w tym środowisku od zaprzestania odbywania zasadniczej służby wojskowej w Wojsku Polskim od 2010 roku. Stwierdziła, że podłoże zachowań samobójczych w wojsku jest złożone. Na pewno do samozniszczenia prowadzi specyficzny syndrom sytuacyjny (instytucjonalne zamknięcie środowiskowe), a także dezorganizacja życia rodzinnego, wyrwanie ze środowiska rodzinnego, sąsiedzkiego oraz koleżeńskiego, jak również nieprzystosowanie do nowego, odmiennego od wcześniej prowadzonego trybu życia (Jarosz 2013a, s. 152-158).

W społeczeństwie polskim próby samobójcze są znacznie częstsze niż zakończone zgonem, w wojsku proporcje te są wyraźnie odwrócone. Śmierć samobójcza oznacza ostateczne zerwanie więzi ze środowiskiem i światem żyjących. Taką skuteczną, „twardą” metodą pozbawienia się życia przez powieszenie wybiera w Polsce ponad 50\% żołnierzy samobójców (w skali całego kraju - 80\%). Drugim narzędziem pozbawienia się życia jest broń pal- 
na (39\% zmarłych samobójców). Żołnierze służby zasadniczej kilkakrotnie częściej próbują pozbawić się życia niż żołnierze kadry zawodowej, liczniej też umierają śmiercią samobójczą. Także czas trwania służby wojskowej jest czynnikiem stymulującym częstość zachowań samobójczych. W okresie pierwszych sześciu miesięcy wcielenia do wojska miało miejsce 52\% samobójstw dokonanych i 60\% prób samobójczych (Jarosz 2013a, s. 157-158).

Konstatacja ta dobrze koresponduje z socjologiczną teorią samobójstw, zgodnie z którą nagła zmiana, wejście w nowe role społeczne i w nowe nieakceptowane warunki sytuacyjne, są dla wielu ludzi doświadczeniem wyjątkowo stresującym.

Podłoże zachowań samobójczych w wojsku jest, oczywiście, złożone. Negatywny syndrom sytuacyjny, prowadzący do samozniszczenia, ma często swoje źródła w instytucjonalnym zamknięciu środowiskowym (czyli w specyfice wojska jako instytucji totalnej), jak i dezorganizacji życia rodzinnego. Skoro bowiem armia jest częścią współczesnego społeczeństwa, stanowiąc raczej jego odbicie niż nieprzystający element, to i zachowania ludzi - także samobójcze - podlegają zbliżonym, porównywalnym prawidłowościom (Jarosz 2013a, s. 158).

Ogromny dorobek naukowy profesor Marii Jarosz w zakresie badań nad zjawiskiem samobójstwa pozostaje pod wielkim wpływem teorii Émile’a Durkheima. Można też zauważyć, że jej badania i konstatacje badawcze potwierdzają niesłabnącą ,aktualność Durkheimowskiej teorii samobójstw w społeczeństwie XXI wieku” (Jarosz 2013a, s. 170). Oczywiście struktura przestrzenna i zawodowa samobójców znacznie różni się od tej z końca XIX wieku, jednak ,czynniki sytuacyjne (zmienna niezależna) wciąż najsilniej stymulują sposoby reakcji na nie dużych grup społeczeństwa (zmienna zależna)". Maria Jarosz za Durkheimem zauważa, że: „współczynniki śmierci samobójczej rosną w okresie dezintegracji społeczeństwa, charakteryzującej zwłaszcza czasy transformacji gospodarczych, politycznych i społecznych («syndrom wielkiej zmiany»), maleją zaś w latach względnej stabilizacji - a także wtedy, gdy społeczeństwo integruje się w obronie wspólnych wartości (wojny, rewolucje)" (Jarosz 2013a). Samobójstwa mają złożone, niekiedy ukryte przyczyny, jednak dzięki dostępnym danym można je analizować i wyciągać wnioski.

Ciekawe są rozmyślania prof. Marii Jarosz dotyczące drugiej dekady XXI wieku w Polsce. Pytała ona o to, w jaki sposób można ograniczyć liczbę samobójstw w Polsce. Uznała, że sam wzrost gospodarczy nie wystarczy. „Rzeczą pierwszoplanową pozostaje przeciwdziałanie nierównościom społecznym: 
materialnym, regionalnym i edukacyjnym" (Jarosz 2015a, s. 16). Niezależnie od zindywidualizowanych motywów i okoliczności samobójstwa w Polsce mają określone rozmiary, strukturę i tendencje odzwierciedlające pośrednio wielkie procesy społeczne, których cząstkę stanowią. Z przeprowadzonych analiz socjologicznych wynika, że typowy samobójca to mężczyzna czterdziestoparoletni, mieszkający na wsi lub w małym mieście, pracujący fizycznie (rolnik, robotnik) lub bezrobotny, od niedawna owdowiały lub rozwiedziony.

Pod wpływem badań naukowych Marii Jarosz powstało wiele inspiracji, aktywizujących do naukowych eksploracji kolejne pokolenia badaczy. Tak jak dla prof. Marii Jarosz naukowym autorytetem był Émile Durkheim, tak dla wielu współczesnych badaczy takim klasykiem jest prof. Maria Jarosz. Można tu wymienić m.in. prace Adama Czabańskiego, Włodzimierza Adama Brodniaka i Krzysztofa Rosy, którzy wielokrotnie odnosili się do dorobku naukowego Marii Jarosz, opisując społeczne mechanizmy samobójstw altruistycznych. W Polsce rośnie zainteresowanie badaczy fenomenem samobójstw, które koncentruje się na różnych jego aspektach.

Analizowane przez socjologów trendy śmierci samobójczej są ważną oznaką dezintegracji i dysfunkcji państwa, stanowią ważny element wiedzy o społeczeństwie. Trudno przewidzieć, czy dokonujące się procesy transformacji systemowej przyczynią się do integracji społeczeństwa czy też do jego dezintegracji, pociągającej za sobą niepożądane, negatywne konsekwencje. Rzeczywistość społeczna jest złożona i zmienna (płynna), a świadomość społeczeństwa kształtuje się w procesie długotrwałych doświadczeń (Jarosz 2002, s. 11)

\section{THE SUICIDE PROBLEM IN TERMS OF MARIA JAROSZ}

\section{Sum mary}

The article describes the scientific achievements of Maria Jarosz, who is considered one of the most distinguished female suicide researches in Poland. Maria Jarosz, using data from the Central Statistical Office, made unique and insightful analysis of the suicide phenomenon. In her research, she associated the phenomenon of suicide with macro-social phenomena, such as the economic crisis, unemployment, changes in lifestyles in urban and rural environments.

Keywords: suicide; social determinants; society

Słowa kluczowe: samobójstwo; uwarunkowania społeczne; społeczeństwo 


\section{BIBLIOGRAFIA}

Durkheim É. (2006), Samobójstw. Studium z socjologii, tłum. K. Wakar, Warszawa.

Hołyst B. (1968), Samobójstwa w Polsce i w niektórych innych państwach, „Zdrowie Psychiczne” nr 2, s. 22-23.

Hołyst B. (1983), Samobójstwo - przypadek czy konieczność?, Warszawa.

Hołyst B. (2012), Suicydologia, Warszawa.

Hołyst B. (2013), Dynamika i struktura samobójstw w Polsce, w: Kondycja psychiczna społeczeństwa polskiego a samobójstwa, red. B. Hołyst, Warszawa, s. 11-290.

Jarosz M. (1975), Wybrane zagadnienia patologii spolecznej, Warszawa.

Jarosz M. (1977), Samobójstwa i ich społeczne determinanty, „Studia Socjologiczne” nr 3, s. 325-350 .

Jarosz M. (1978), Le suicide en Pologne, „Revue d'études comparatives est-quest”, nr 4, s. 65-101. Jarosz M. (1979), Problemy dezorganizacji rodziny. Determinanty i spoleczne skutki, Warszawa.

Jarosz M. (1980), Samoniszczenie. Samobójstwo. Alkoholizm. Narkomania, Wrocław.

Jarosz M. (1985), Suicides in Poland as an Indicator of Social Disintegration, „Social Indicators Research", nr 4, s. 449-464.

Jarosz M. (1995), Polscy samobójcy i ich cechy społeczno-zawodowe, w: Samobójstwo, red. B. Hołyst i M. Staniaszek, Warszawa-Lódź, s. 9-31.

Jarosz M. (1997), Samobójstwo, Warszawa.

Jarosz M. (1999), Rezygnacja z życia: analiza socjologiczna zjawiska samobójstwa w Polsce, „Ethos”, nr 3, s. 115-126.

Jarosz M. (2002), Samobójstwo, w: Encyklopedia socjologii, t. 4, red. W. Kwaśniewicz, Warszawa, s. $9-12$.

Jarosz M. (2004), Samobójstwo: ucieczka przegranych, Warszawa.

Jarosz M. (2005a), Suicides, thum. W. Gaignebet, Paris.

Jarosz M. (2005b), Samobójstwa w III Rzeczypospolitej w perspektywie światowej. Analiza socjologiczna, „Suicydologia”, t. I, s. 1-13.

Jarosz M. (2012), Ludzie i instytucje. Samobójstwa jako wskaźnik dezintegracji społecznej, w: Instytucje: konflikty i dysfunkcje, red. M. Jarosz, Warszawa, s. 298-329.

Jarosz M. (2013a), Samobójstwa. Dlaczego teraz?, Warszawa.

Jarosz M. (2013b), Polskie bieguny. Społeczeństwo w czasach kryzysu, Warszawa.

Jarosz M. (2015a), Samobójstwa w czasach kryzysu, „Suicydologia”, t. VII, s. 5-17.

Jarosz M., Kozak M.W. (2015b), Eksplozja nierówności?, Warszawa.

Jarosz M., Kozak M.W. (2016), Poza systemem. Instytucje i spoteczeństwo, Warszawa.

Jarosz M., Krawczyk J. (1995), Niektóre przejawy patologii spolecznej - samobójstwa i przestępczość, w: Prywatyzacja polskiej gospodarki w ujęciu regionalnym. Aspekty społeczno-ekonomiczne, red. M. Jarosz, Warszawa, s. 93-119.

Jarosz M. red. (2010), Polacy równi i równiejsi (Klasy i warstwy we wspótczesnym społeczeństwie polskim), Warszawa.

Jarosz M. red. (2005), Wygrani i przegrani polskiej transformacji, Warszawa.

Jarosz M. red. (2008), Wykluczeni. Wymiar społeczny, materialny i etniczny, Warszawa.

JANUSZ MARIAŃSKI - profesor zwyczajny doktor habilitowany, socjolog specjalizujący się w socjologii moralności i socjologii religii. Wieloletni wykładowca Katolickiego Uniwersytetu Lubelskiego Jana Pawła II. Od 1984 roku aż do przejścia na emeryturę kierownik Katedry Socjologii Moralności w Instytucie Socjologii KUL. Wieloletni członek Prezydium Polskiej Akademii Nauk oraz członek 
Centralnej Komisji do Spraw Stopni i Tytułów Naukowych. Autor ponad tysiąca publikacji naukowych, w tym kilkudziesięciu książek.

Adam Czabański - doktor habilitowany, socjolog i suicydolog. Wykładowca Uniwersytetu Medycznego im. Karola Marcinkowskiego w Poznaniu. Kierownik Pracowni Socjologii Zdrowia i Patologii Społecznych w Katedrze Nauk Społecznych i Humanistycznych. Członek zarządu Polskiego Towarzystwa Suicydologicznego. Autor 220 publikacji naukowych, w tym 11 książek. 